\title{
Research
}

\section{Biological and Ecological Mechanisms Supporting Marine Self- Governance: the Seri Callo de Hacha Fishery in Mexico}

\author{
$\underline{\text { Xavier Basurto }}^{1,2,3}$
}

\begin{abstract}
My goal was to describe how biological and ecological factors give shape to fishing practices that can contribute to the successful self-governance of a small-scale fishing system in the Gulf of California, Mexico. The analysis was based on a comparison of the main ecological and biological indicators that fishers claim to use to govern their day-to-day decision making about fishing and data collected in situ. I found that certain indicators allow fishers to learn about differences and characteristics of the resource system and its units. Fishers use such information to guide their day-to-day fishing decisions. More importantly, these decisions appear unable to shape the reproductive viability of the fishery because no indicators were correlated to the reproductive cycle of the target species. As a result, the fishing practices constitute a number of mechanisms that might provide short-term buffering capacity against perturbations or stress factors that otherwise would threaten the overall sustainability and self-governance of the system. The particular biological circumstances that shape the harvesting practices might also act as a precursor of self-governance because they provide fishers with enough incentives to meet the costs of organizing the necessary rule structure that underlies a successful self-governance system.
\end{abstract}

Key Words: Atrina tuberculosa; callo de hacha; common-pool resources; diving fisheries; Gulf of California; Mexico; pen shells; Pinna rugosa; resilience; scallop; Seri; small-scale fisheries; socialecological systems

\section{INTRODUCTION}

Understanding how successful fisheries selfgovernance can be achieved is of considerable importance. Small-scale fisheries employ 50 million of the world's 51 million fishers, practically all of whom are from developing countries, and produce more than half of the world's annual marine fish catch of 98 million tonnes (Berkes et al. 2001). In addition, the overexploitation of small-scale fisheries is threatening many coastal habitats and ecosystem-based processes upon which depend many other marine and terrestrial species, including human beings (Pauly et al. 1998, Jackson et al. 2001, Myers and Worm 2003, Berkes et al. 2006). Clearly, there is an urgent need for the reform of management and governance of small-scale fisheries. However, academics, policy makers, and practitioners still have few theoretical tools with which to better understand how to avoid overexploitation while promoting sustainable outcomes.
A promising approach that is making significant contributions to the understanding of how successful collective action can avoid overexploitation is the study of institutions for governing and managing common-pool resources. Small-scale fisheries are an example of this (Ostrom et al. 1994, Ostrom et al. 2002, Ostrom 2005). In this school of thought, institutions are viewed as the set of formal and/or informal rules that is used by a group of individuals to govern their interactions (North 1990, Ostrom 1990). Common-pool resources are defined by: costly exclusion of other potential users of the resource; and extractability, i.e., units of the resource that are extracted by one individual are not available to anyone else. The possibility that common-pool resources would be subject to free riding and crowding has led scholars to assume that common-pool resources would always be overused (Scott 1955, Hardin 1968). In the last 20 years, however, considerable evidence has successfully challenged the ability to generalize this assumption (Ostrom et al. 2002). As a result, a general theory 
of institutional change has started to emerge that explicitly recognizes that common-pool resources and their users vary with regard to a number of key attributes (McCay and Acheson 1987, Berkes 1989, Pinkerton 1989, Wade 1994, Baland and Platteau 1996, Ostrom et al. 2002, Ostrom 2005). Moreover, Ostrom $(2005,2007)$ has stated that the ability of common-pool resources users to self-organize and to succeed or fail to engage in collective action to design institutions that are able to avoid the tragedy of the commons (Hardin 1968) depends on how attributes of the resource and attributes of the users interact with each other.

The next steps forward are to better understand the attributes of the users and the resources and how they combine with each other in specific settings (Agrawal 2002). Toward this goal, the attributes of the users have received significant attention in the common-pool resources literature. For instance, scholars have studied the effects of heterogeneity (Varughese and Ostrom 2001, Bardhan and DaytonJohnson 2002), history (Netting 1981, McCay and Acheson 1987), resource salience (Gibson 2001), trust and reciprocity (Ostrom and Ahn 2003), autonomy from higher levels of governance (Carpenter 2001), and local leadership (Schneider and Teske 1995). Together, these factors affect a group's ability to self-organize and to sustain their use of common-pool resources successfully.

More recently, the characteristics of the resource system and the resource units have received increased attention from scholars (Schlager et al. 1994, Berkes and Folke 1998, Levin 1999, Wilson 2002, Turner et al. 2003, Lansing 2006, Ostrom 2007). The accumulation of biophysical data relevant to understanding self-governance mechanisms in specific linked social-ecological systems has been slower to emerge, partly because of the elevated costs of measuring ecological variables. In addition to current efforts to develop a body of literature on the dynamics of social-ecological systems, my objective was to describe the role that the resource system and resource units play in a small-scale fishing system in northwest Mexico that has successfully engaged in self-governance. The development of an in-depth understanding of the resource system and the resource units for a case that is known to be self-governed successfully (Basurto 2005) is an important task given the limited knowledge about what types of resource systems and resource units' dynamics might or might not be conducive to self-governance scenarios. In light of this, my goal was to describe how biological and ecological factors give shape to fishing practices that can contribute to the successful self-governance of a small-scale fishing system in the Gulf of California, Mexico. Toward this goal, I first introduce the setting in which the fishery takes place. I then describe the research strategy that allowed the identification of ecological and biological indicators that allow the emergence of fishing practices. In the discussion, I describe what these fishing practices look like, explore whether the fishing practices might be affecting the reproductive viability of the biological resource or contributing to biological resilience, and elaborate on how the fishing practices might facilitate the successful self-governance for which this fishing system is well known.

\section{SERI FISHING INSTITUTIONS}

In northwest Mexico, there is a self-governed smallscale fishing community of a native seafarer group known as Seri or Comcaác. Before becoming sedentary early in the 20th century, the Seri people were hunters and gatherers who were organized in bands that occupied an extensive portion of the coastal Sonoran Desert and inhabited various islands of the Gulf of California, including Tiburon, Mexico's largest island (Fig. 1; Sheridan 1999, Bowen 2000). Today, all of the Seri live in two permanent villages: Punta Chueca and El Desemboque. According to the Instituto Nacional de Estadística y Geografía (2005), the total population oscillates around 600 people. As one of the smallest ethnic groups in Mexico, the federal government granted the Seri legal property rights to a portion of their historic coastal territory in the 1970s. The goal was to increase the Seri's chances of survival by reducing the probability of future conflicts with other local fishing settlements of different ethnic origin. Property rights took the form of the ejido of El Desemboque and its annex of Punta Chueca (Diario Oficial de la Federación 1970), communal tenure on Tiburon Island (Diario Oficial de la Federación 1975b), and a fishing concession granted to the Seri fishing cooperative (Diario Oficial de la Federación 1975a).

Today, the main source of income for the Seri community of Punta Chueca is the callo de hacha (CDH; scallop) fishery. CDHs are sessile bivalve mollusks like oysters or clams that live buried in sandy bottoms; they are harvested regularly by 
Fig. 1. Location of the Infiernillo Channel and the Seri fishing village of Punta Chueca. The dotted line indicates the ejido boundary.

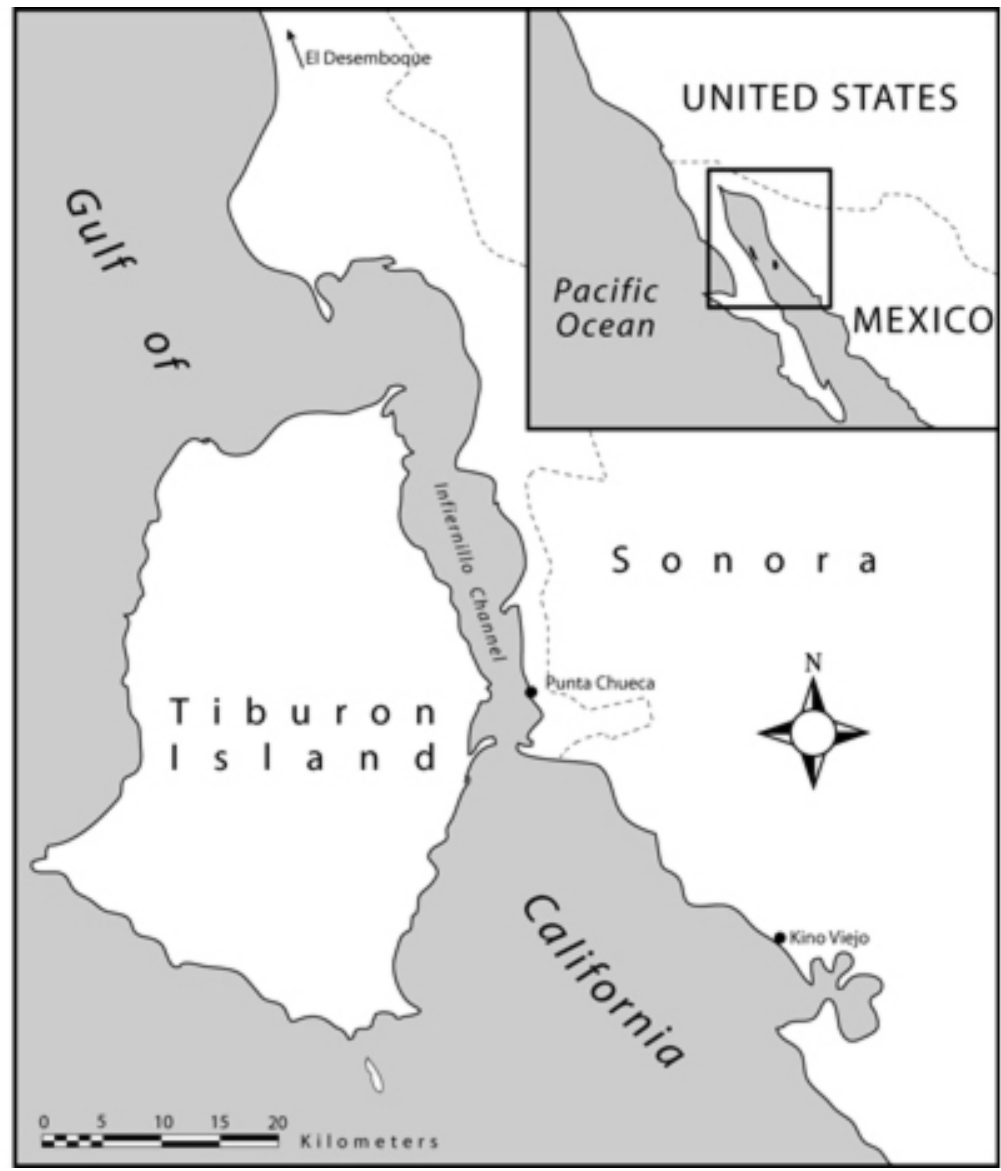

divers for the abductor muscle (Basurto 2006). The number of boats that participate in the fishery has been documented to vary between 5 and 20 , and each fishing crew has on average three members (Basurto 2006). According to historic accounts, this fishery has maintained stable annual production for almost 30 years (Basurto 2005). The Mexican national market value for this seafood is high; in 2001, fishers received between US\$9 and $\$ 18$ per kilogram of CDH (Basurto 2005). All commercial divers use a rudimentary underwater breathing apparatus called hookah adapted to a small $(\sim 8 \mathrm{~m})$ fiberglass outboard motorboat. Given that $\mathrm{CDHs}$ live almost completely buried in the sand, divers must learn to spot them and to use a hook to detach them from the bottom (Basurto 2006).
All of the Seri CDH fishery takes place in the Infiernillo Channel, a long $(41 \mathrm{~km})$, narrow, and shallow body of water that runs south to north and is flanked on the west by Tiburon Island and to the east by the continental coast of the Mexican state of Sonora (Fig. 1). The Infiernillo Channel contains the most extensive eelgrass (Zostera marina) meadows of the region (Torre-Cosío 2002). It is also home to the most abundant beds of the two most commercially important CDH species in northwest Mexico: Atrina tuberculosa and Pinna rugosa. These species, however, have been overfished in fishing areas neighboring the Infiernillo Channel (Moreno et al. 2005).

Overexploitation outside the Infiernillo Channel and the rich abundance inside it generates pressure 
from non-Seri fishers to gain access to Seri $\mathrm{CDH}$ fishing grounds. In response, the Seri have designed a number of rules-in-use to grant or prohibit access and withdrawal rights (Schlager and Ostrom 1992) in the Channel to non-Seri fishers. Because Mexican government fisheries officials lack a presence in the area, the Seri have self-governed their fishery without any interference from higher levels of the Mexican government since the mid-1980s (Basurto 2006). A study of the Seri rules-in-use structure has provided an initial understanding of the mechanisms that the Seri community have in place to successfully monitor and enforce access by non-Seri fishers and control use by authorized entrants to the fishery (Basurto 2005). Seri fishers have devised rules to limit fishers' harvests, harvest locations, and who can enter and participate in the fishery, as well as mechanisms to monitor that the rules are followed and to enforce them against rule-breakers (Basurto 2005).

These are exciting findings given the general agreement that the establishment of low-cost monitoring and enforcement mechanisms are an important condition for successful local selfgovernance (Stern et al. 2002). Indeed, it is likely that along with Seri de jure property rights over the Infiernillo Channel, the Seri's ability to monitor and enforce their locally designed institutions has played a key role in the emergence of the Channel's self-governance system. Given that there is a good basic understanding of the structure of Seri institutions (Basurto 2005) and the social history of the fishery (Basurto 2006), it is now possible to turn to the task of understanding the roles that biological and ecological factors might be playing in the community's capacity for self-governance.

Findings from other self-governing fishing systems indicate that fishers often rely on a variety of indicators of the resource system or resource units to make their day-to-day management decisions. For instance, because Maine lobster fishers can easily identify gravid female lobsters, they have agreed to mark the shell of such individuals with a $\mathrm{v}$-notch to signal to each other that the marked individual is a proven breeding female that is not to be harvested (Acheson 2003). I next describe how I identified the ecological and biological indicators that allow the emergence of fishing practices and what these fishing practices might look like in the Seri case.

\section{RESEARCH STRATEGY}

My research strategy was centered on understanding what biological factors might allow fishers to make informed decisions about what and where to fish, and how fishing practices might be able to shape the reproductive viability of the target population.

\section{Identification of fishing areas and composition of the catch}

Fishing areas are those places that are purposely selected by fishers because they are deemed as especially suitable for the harvest of callo de hacha $(\mathrm{CDH})$. To identify different fishing areas and their relative frequency of use, I conducted informal, formal, and in-depth interviews (e.g., Bernard 1995). In essence, the main question that I asked fishers was: What are the biological factors that influence where to go to fish and what to fish? Informal interviews were conducted mostly while participating in fishing activities and eventually encompassed approximately $75 \%$ of all fishers operating in the Infiernillo Channel at the time. Formal interviews took the form of mapping interviews in which approximately $50 \%(\mathrm{n}=24)$ of all fishers identified the locations that had been used for the longest periods of time to fish $A$. tuberculosa during specific time periods. A. tuberculosa was the main species harvested during the study period. Mapping interviews were conducted individually or in focus groups, generally in the evening at the fishers' homes and once fishing activities had ended and fishers had time to relax and talk. In the same manner, I conducted 12 in-depth semi-structured interviews with experienced fishermen acting as key informants. The in-depth interviews were recorded (or not, at the interviewee's desire) and transcribed. The transcriptions were handed back to the interviewees for their revision and further clarification of important points. All conversations and interviews with fishermen were conducted in Spanish. To support the information gathered through interviews, I also reviewed two fishermen's fishing journals, participated in fishing trips, and recorded the fishing area's geographic positions with the guidance of experienced fishers of the Seri community. Most data collection took place between June 2000 and July 2001 for a total of 98 days in the field; however, I began in 1998 to build rapport to perform participatory research in the community. 
Because of the presence of extensive Z. marina eelgrass meadows in the Channel and reports indicating that CDHs can grow in the same areas (Butler and Keough 1981, Kuhlmann 1998, Richardson et al. 1999), it was important to assess how the presence of eelgrass meadows in the Channel affected temporal and spatial fishing patterns. The assessment was done through direct observation and mapping interviews with fishermen.

As my experience and participation in fishing trips increased, I began to ask fishers why they chose to fish in some areas over others and what explained the species, size, and sex ratios obtained in their harvests. Eventually, I was able to attest that most fishers agreed that differences in $\mathrm{CDH}$ abundance and variation in abductor muscle size among different fishing areas played an important role in choosing to fish in some areas over others at particular time periods. Given that CDHs are harvested for their abductor muscle, it makes sense that fishers would pay attention to these differences. Interestingly, key informants declared that shell size was not a reliable indicator of abductor muscle size. Most fishers also mentioned that they were able to conduct selective harvests given their ability to distinguish differences between species ( $A$. tuberculosa vs. $P$. rugosa) and sizes before harvesting them. However, fishers said that they were unable to determine the CDHs' sex before harvesting by looking at the shell or abductor muscle alone. To verify if this information collected in interviews indeed played a role in shaping fishers' harvests, I conducted a comparison between the fishers' claims and data collected in situ. The in-situ data consisted of assessments of the composition of the $\mathrm{CDH}$ catch and an underwater survey of two fishing areas.

To assess the composition of the $\mathrm{CDH}$ catch (i.e., A. tuberculosa), I participated in $32 \mathrm{CDH}$ fishing trips roughly equally distributed in four sampling events conducted every three months within the span of 1 year. Initially, my selection of fishing trips was opportunistic and biased toward those fishermen that already knew me and were willing to take an extra person in their small boats. It progressively included other fishers I had not met before as they became used to my presence in the community and became curious about me and my work. By the end, I had participated in fishing trips and geo-referenced the fishing areas in use by the majority of fishers operating in the Channel at the time. Data recorded for CDH individuals sampled during harvest included: sex, degree of sexual maturity, shell size, and size of the abductor muscle. Shell size was determined as the maximum length in centimeters of one of the two valves of each animal. Abductor muscle size was determined as the maximum diameter to the nearest $0.1 \mathrm{~mm}$. These measurements were done using a measuring board and micrometric caliper, respectively. Except for the abductor muscle size, the rest are standard measures used in population and reproductive biology studies of similar or related species (Ahumada-Sempoal et al. 2002, Moreno et al. 2005). These measures were chosen either because fishers had mentioned them as important in their choice of fishing sites (i.e., species or size of the abductor muscle) or because they would be useful to determine basic population biology parameters about the species. Given that this is a species with a continuous reproductive cycle, it is possible to determine the sex and sexual maturity of an individual in at least 11 months of the year (Moreno et al. 2005).

In addition, during July of 2000, I conducted an underwater survey of two fishing areas to aid the assessment of fishers' ability to conduct selective harvests by size and species. The purpose of the underwater surveys was to assess if there were statistically significant differences in size and species between organisms obtained in fishers' harvests and the sum of organisms censed in the underwater survey and those collected in the harvest. The underwater survey consisted of a census of all CDHs encountered within a $300 \mathrm{~m}^{2}$ transect. With the help of a 30-m guide line submerged and extended in a straight line over the bottom, two divers harvested all CDHs found within $5 \mathrm{~m}$ of each side of the line. Approximately $10 \%$ of the estimated area of two fishing locations in use by the fishery was surveyed: two dives in Paredones and three dives in Hona iyat (Fig. 2). The criteria to select and sample only two fishing areas hinged on the necessity of: censusing a fishing location that was used by the fishing fleet as recently as possible and for which I had censed their entire catch for the day, and minimizing the negative effect that the extraction and sacrifice of the totality of the CDHs inhabiting in these areas could have for their productivity in the future.

Finally, fishers also mentioned that different fishing areas yielded different sizes of abductor muscle throughout the season. Furthermore, fishers 
Fig. 2. Locations of the fishing areas in use within the Infiernillo Channel between summer 2000 and summer 2001. Not all fishing areas listed in Table 1 are shown.

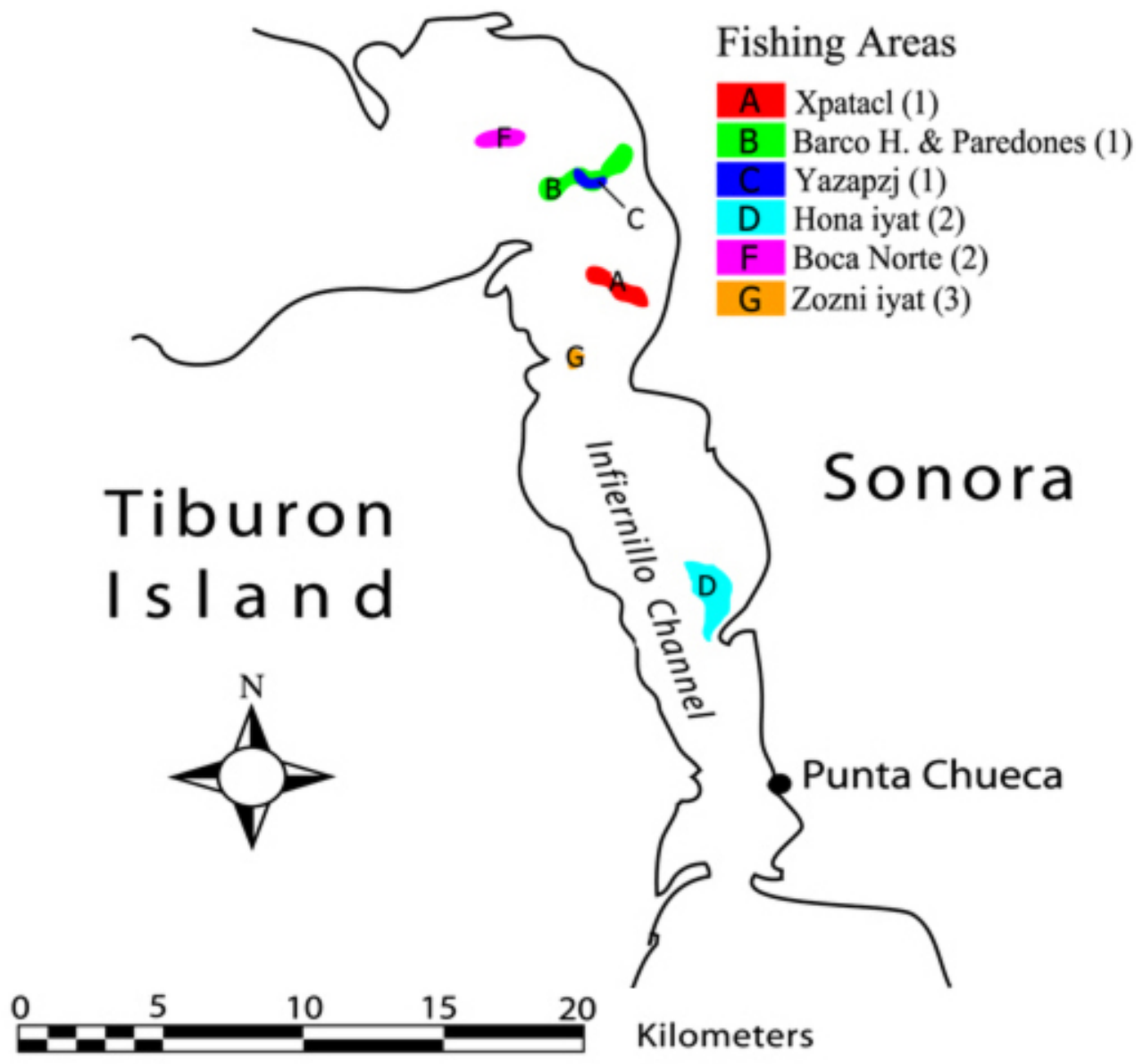
(1) Visited several times within a year
(2) Visited generally only once a year
(3) Visited generally only once every few years

Kilometers

declared that shell size was not a reliable indicator of abductor muscle size. If fishers could not know the size of the abductor muscle unless they harvested and opened the $\mathrm{CDH}$, the only way to learn which fishing areas have the largest abductor muscle sizes at different times of the year would be through the accumulated harvesting experiences of fishers. To corroborate these claims, I conducted statistical tests (ANOVA) of shell and abductor muscle size distributions of $A$. tuberculosa at four fishing areas on a sample of fishers' harvests. This sampling was performed during both the hot season (24-26 July 2000) and cold season (30 September and 1 October 2000), between which fishers reported observing the largest differences in muscle size.

\section{Are fishing practices affecting the viability of the callo de hacha's reproductive population?}

To understand if Seri fishers' harvests might be selectively targeting one sex over the other and thus threatening the viability of the reproductive population, I asked fishers if they could distinguish males from females. Fishers' responses suggested that they could not. To assess their assertion, I estimated the sex ratio of a random sample of the harvests, examined if there was a correlation between shell and abductor muscle size differences related to sexual dimorphism, and reviewed the literature to determine what the reproductive cycle of CDHs is like for the species in this region. The sex determination of adult individuals was done 
visually by observing the highly conspicuous gonads of each harvested specimen. In the CDHs, as in other gonochoristic (separate sex) bivalve species, mature female gonad tissue presents itself as bright orange, whereas that of males is usually white to ivory (Strathmann 1987). To assess if the CDHs were externally sexually dimorphic, shell and abductor muscle size distributions of both sexes were examined statistically using t-tests, and the sex ratio was determined by conducting a chi-square test of the average sex ratio of two different fishing areas during the same climatic season.

\section{FINDINGS}

\section{Identification of fishing areas and composition of the catch}

\section{Fishing areas usage}

Most fishers that I interviewed mentioned nine main different fishing areas as the most important for the fishery for the years 2001-2002: fishing areas A, B, C, D, E, F, G, H, and I (Table 1). Only six of the areas were mapped because they were the only areas observed in use by fishers during the sampling period (areas A, B, C, D, F, and G; Fig. 2). Fishers mentioned that different fishing areas varied in their frequency of use depending on the species targeted (either A. tuberculosa or $P$. rugosa). For $A$. tuberculosa, some fishing areas were used throughout the year (areas A, B, and C), other areas were generally visited only once a year (areas D, E, and $F$ ), and others were generally visited only once every few years (areas $\mathrm{G}$ and $\mathrm{H}$; Table 1).

\section{Selecting for fishing areas according to abductor muscle size}

Fishers said that the size of the abductor muscle influenced their selection of fishing areas and that, at least for $A$. tuberculosa, there were differences in the abductor muscle size among fishing areas A, B, $\mathrm{D}$, and G. Fishers stated that these differences did not seem related to shell size, which was supported by the ANOVA $\left(\mathrm{F}_{3,2736}=141.70, \mathrm{p}<0.05\right.$; Fig. 3$)$. Fishing area $\mathrm{D}$ was particularly identified by fishers as a site where not particularly big or small shell sizes could be found, but where the abductor muscle size was generally smallest, which was also supported by the ANOVA $\left(\mathrm{F}_{3,945}=511.16, \mathrm{p}<0.05\right.$; Fig. 3).
Do eelgrass meadows shape fishing behavior?

Direct observations showed that fishers generally tried to avoid diving in $Z$. marina meadows and to a lesser extent in meadows formed by the green algae Caulerpa spp., even when they knew that callo de hachas (CDHs) were abundant in these locations. Fishers restrict their harvesting operations to sandy areas or clear patches between the meadows. Some of the reasons that were mentioned for avoiding these areas were the difficulty of harvesting CDHs because of the need to remove eelgrass or algae and the risk of stepping on stingrays or swimming crabs. For the period of 2000-2001, Z. marina meadows were mostly present in the Channel from October to May, whereas Caulerpa spp. were present from June to October. These seasonal patterns conform to fishers general observations.

Can fishers shape the composition of the catch by species and size?

All fishers asserted that the species targeted play an important role in the selection of fishing areas and that they can distinguish between species $A$. tuberculosa and $P$. rugosa before unburying them by looking at the shell and the shape and color of the mantle, which is a thin membrane that surrounds the body of a bivalve and protects and separates the organs from direct contact with the shell (Helm et al. 2004). To assess this claim in two fishing areas, I conducted a chi-square test and found significant differences in the composition of species between the fishers' harvests and the sum of organisms censed in the underwater survey plus those collected in the harvest (Table 2). The disproportionately large abundance of $A$. tuberculosa in fishers' catches compared to the abundance in the sum of fishers' catches and the underwater survey in both of the sampled fishing areas supports the fishers' claim.

I also assessed the fishers' claim that they can distinguish the individual's size prior to extracting A. tuberculosa from the bottom. The average size of A. tuberculosa in the fishers' catch was significantly greater than that in the underwater census in the two fishing areas sampled (fishing area A: $\mathrm{t}_{145}=16.30, \mathrm{p}<0.01$; fishing area $\mathrm{D}: \mathrm{t}_{246}=15.09$, $\mathrm{p}<0.01$; Fig. 4). 
Table 1. Patterns of use of various fishing areas.

\begin{tabular}{|c|c|c|}
\hline Pattern of use & $\begin{array}{l}\text { Fishing } \\
\text { area code }\end{array}$ & Name of fishing area $\dagger$ \\
\hline Visited several times per year & $\begin{array}{l}\text { A } \\
\text { B } \\
\text { C }\end{array}$ & $\begin{array}{c}\text { Xpatacl (=Almo) } \\
\text { Barco H. and Paredones } \\
\text { Yazapzj }\end{array}$ \\
\hline Visited generally only once per year & $\begin{array}{l}\mathrm{D} \\
\mathrm{E} \\
\mathrm{F}\end{array}$ & $\begin{array}{c}\text { Hona iyat } \\
\text { Quipcö Coospoj (=Campo Víboras) } \\
\text { Boca Norte }\end{array}$ \\
\hline Visited generally only once every few years & $\begin{array}{l}\mathrm{G} \\
\mathrm{H}\end{array}$ & $\begin{array}{c}\text { Zozni iyat } \\
\text { Sacpátix (=Punta Palo Fierro) }\end{array}$ \\
\hline Only visited when harvesting Pinna rugosa & $\mathrm{I}$ & Chorales Hona \\
\hline
\end{tabular}

$\dagger$ Names are given in Comcáac, Spanish, or both, as they are used by fishers. Only fishing areas that were mentioned by $>20$ fishers $(83 \%, \mathrm{n}=24)$ are included. Data sources: GPS waypoints during fishing trips between June 2000 and June 2001, mapping interviews, fishers' journals, and data available form other sources.

\section{Are fishing practices affecting the viability of the callo de hacha's reproductive population?}

Most fishers mentioned that it is not possible to determine the sex of CDHs by looking at the shell or abductor muscle alone; my findings corroborated this claim. The sex ratio of the catch of $A$. tuberculosa was 1:1 (average of 53\% females and $47 \%$ males; $\mathrm{SE}=2.9$ ) in four different fishing areas that were chosen randomly from the pool of data collected for all fishing areas. This finding is consistent with other reports for A. tuberculosa and closely related species (Ahumada-Sempoal et al. 2002, Moreno et al. 2005). In addition, a random sample of the fishing catch was analyzed to assess if differences in shell or abductor muscle size are related to sexual dimorphism; they were not (shell size: $\mathrm{t}_{312}=-0.10, \mathrm{p}=0.92$; abductor muscle size: $\left.\mathrm{t}_{93}=-1.24, \mathrm{p}=0.22\right)$.

Regarding the reproductive cycle, scholars have suggested that $A$. tuberculosa has a continuous reproductive cycle, spawning in 5-7 months of the year with one or two well-differentiated peaks (i.e., in July and/or November; Moreno et al. 2005, Niebla Larreta 2006, Angel-Pérez et al. 2007). In addition, it has been reported that the genus Atrina reaches sexual maturity at $\sim 10 \mathrm{~cm}$ in shell length
(Ahumada-Sempoal et al. 2002). This suggests that A. tuberculosa harvested in the Channel had a chance to reproduce at least once before harvesting, given that the great majority of $A$. tuberculosa sampled $(70.2 \% \mathrm{n}=3261)$ measured at least twice the minimum size for sexual maturity (average size $=20.8, \mathrm{SD}=2.53$ ).

\section{DISCUSSION}

I first describe the fishing practices that emerge from my findings and emphasize how they contribute to the biological resilience of the system. I then describe the link between fishing practices and selfgovernance. I propose that Seri fishing practices benefit the maintenance of the self-governance system by providing short-term buffering capacity against sudden perturbations that might send the system into a trajectory of collapse (Turner et al. 2003). I also propose that the particular nature of Seri fishing practices facilitates the emergence of successful self-governance by generating incentives that increase the benefits and lower the costs of organizing and maintaining the rule system. 
Fig. 3. Differences in shell size and abductor muscle size among four fishing areas.

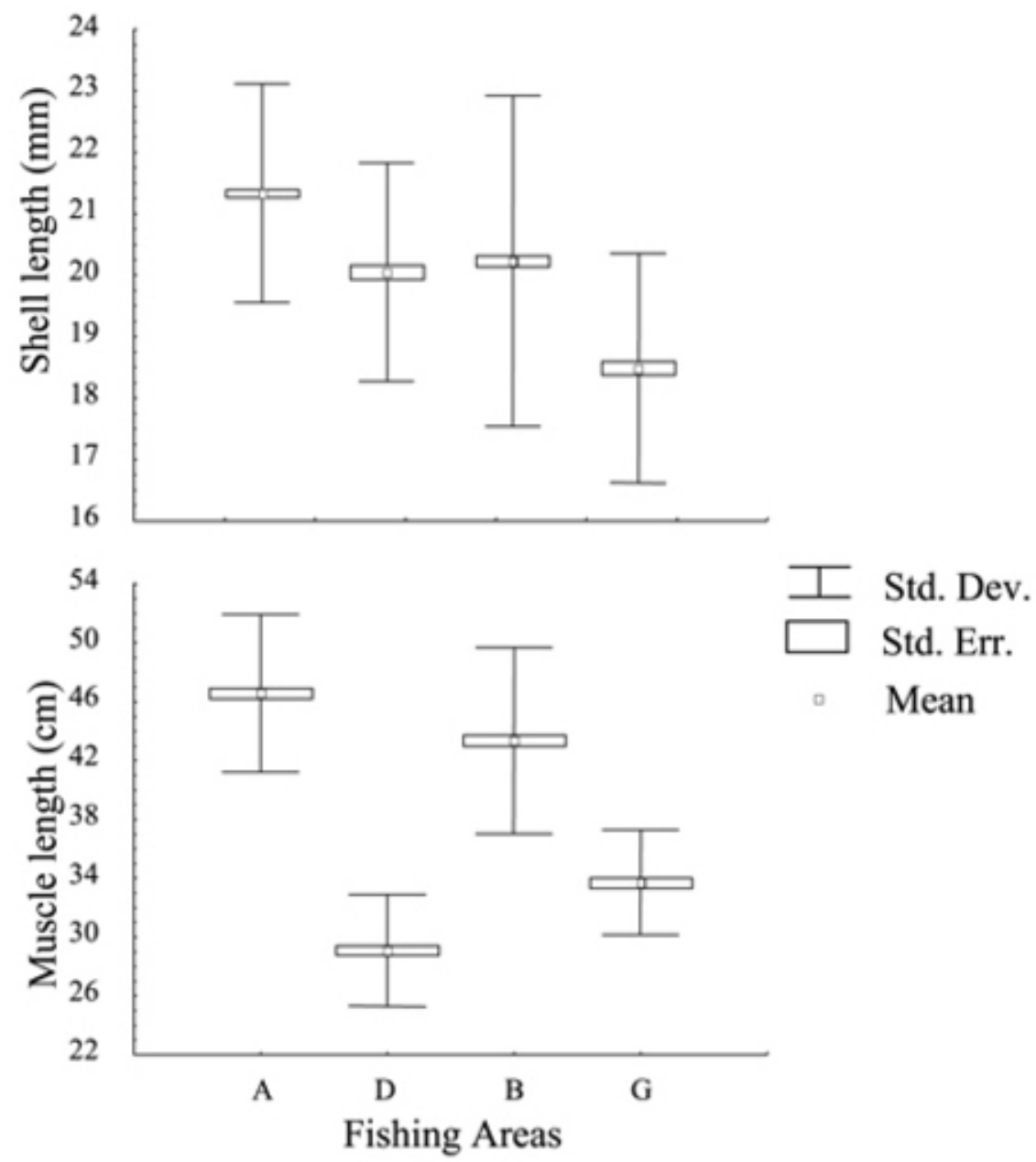

Fishing practices and other factors supporting biological resilience

My findings demonstrate that divers can distinguish among different sizes of $A$. tuberculosa before detaching them from the bottom, so they can choose to conduct size-selective harvests. In $>70 \%$ of the fishers' catch $(\mathrm{n}=3261)$, the fishers selected to harvest individuals $\geq 20 \mathrm{~cm}$ in shell length (average size $=20.8, \mathrm{SD}=2.53$ ). Given that callo de hachas (CDHs) are marketed by weight, fishers have an incentive to select the largest individuals that they can find because it is more cost effective. AhumadaSempoal et al. (2002) reported that Atrina individuals are sexually mature at $10 \mathrm{~cm}$ in shell length. Thus, most of the catch is composed of organisms that had already reproduced at least once, to the likely benefit of the $\mathrm{CDH}$ population. However, in some species of marine organisms, the targeting of older year classes might constitute a threat to the viability of the population given that older and larger individuals expel larger quantities of gametes than do younger specimens (Newell et al. 1982, Parsons et al. 1992); it is unknown if this is also the case for A. tuberculosa and P. rugosa.

My results also indicate that differences in shell size are not correlated with the sex of the individual. The 
Table 2. Comparison of fishers' harvests and fishers' harvests plus unharvested individuals found in the underwater census in two fishing areas sampled within the Infiernillo Channel for two species of callo de hacha.

\begin{tabular}{|c|c|c|c|c|c|c|}
\hline \multirow[b]{2}{*}{ Groups compared } & \multicolumn{3}{|c|}{ Paredones fishing area $\dagger$} & \multicolumn{3}{|c|}{ Hona iyat fishing area $\ddagger$} \\
\hline & Atrina tuberculosa & Pinna rugosa & Abundance ratio & Atrina tuberculosa & Pinna rugosa & Abundance ratio \\
\hline $\begin{array}{l}\text { Composition of fishers' } \\
\text { harvests + underwater } \\
\text { census }\end{array}$ & $\begin{array}{c}81.35 \% \\
(397) \S\end{array}$ & $\begin{array}{l}18.65 \% \\
(91)\end{array}$ & $5: 1$ & $\begin{array}{c}70.32 \% \\
(263)\end{array}$ & $\begin{array}{c}29.68 \% \\
(111)\end{array}$ & $2: 1$ \\
\hline $\begin{array}{l}\text { Composition of fishers' } \\
\text { harvests }\end{array}$ & $\begin{array}{c}93.72 \% \\
(343)\end{array}$ & $\begin{array}{c}6.28 \% \\
(23)\end{array}$ & $15: 1$ & $\begin{array}{c}94.74 \% \\
(198)\end{array}$ & $\begin{array}{c}5.26 \% \\
(11)\end{array}$ & $18: 1$ \\
\hline
\end{tabular}

$\dagger$ The groups were significantly different $\left(\chi^{2}=58.15827, \mathrm{df}=1, \mathrm{p}<0.0001\right)$. $\$$ The groups were significantly different $\left(\chi^{2}=106.1547, \mathrm{df}=1, \mathrm{p}<0.0001\right)$. $\S$ The number of individuals is provided in parentheses.

harvesting selectivity of the fishers affects the age distribution, but not the sex distribution, of the unharvested $\mathrm{CDH}$ population in the Channel. Indeed, sexual dimorphism is very rare in bivalves (Sastry 1979), and other dioecious (separate sexes) species that are related to $\mathrm{CDHs}$ have similar population sex ratios (Newell et al. 1982). As a consequence, fishers' decisions about what and where to harvest do not seem able to shape the reproductive viability of the fishery because there are no indicators correlated to the reproductive cycle. Another characteristic of the reproductive cycle that also seems to contribute to the biological resilience of the fishery is the continuous spawning and recruitment strategy of $A$. tuberculosa, which is common to other species of tropical bivalves (Keen 1971). By continuously spawning throughout the year, the $\mathrm{CDH}$ population has a wide variety of size classes scattered among different areas. From a fisheries management perspective, a spawning period that occurs over several months reduces the chance that intense fishing pressure at one time of the year might severely affect the reproductive population and the long-term sustainability of the fishery, as has been the case with many species of grouper that have been overfished when they aggregate to mate (Sala et al. 2001).
Another factor that contributes to the maintenance of the fishery is the fact that the presence of eelgrass Z. marina and algae Caulerpa spp. over up to $12 \%$ of the Channel's bottom constitutes a no-fishing zone for 8 months of the year. During this time, a reproductively viable portion of the $\mathrm{CDH}$ population remains off-limits to the fishery, providing an added layer of support to the biological resilience of the $\mathrm{CDH}$ population in the Channel. Although $Z$. marina meadows provide protection from predators to $\mathrm{CDHs}$, they also reduce water flows and growth rates; however, the relationship is thought to be more beneficial than costly for CDHs (Coen and Heck 1991).

The different interrelated factors that influence fishers' choices of fishing areas (i.e., size, species, and presence of $Z$. marina meadows) allow speculation about the presence of fishing rotation patterns at various timescales in the $\mathrm{CDH}$ fishing system. Although there are no known explicitly articulated rules-in-use, fisher reports, or long-term observations, I infer that the rotation of fishing areas might be taking place because during interviews, fishers mentioned that some fishing areas are used throughout the year, whereas others are generally visited only once a year, and others only once every few years. If rotation is indeed taking place, it would 
Fig. 4. Size selection of callo de hachas by divers.
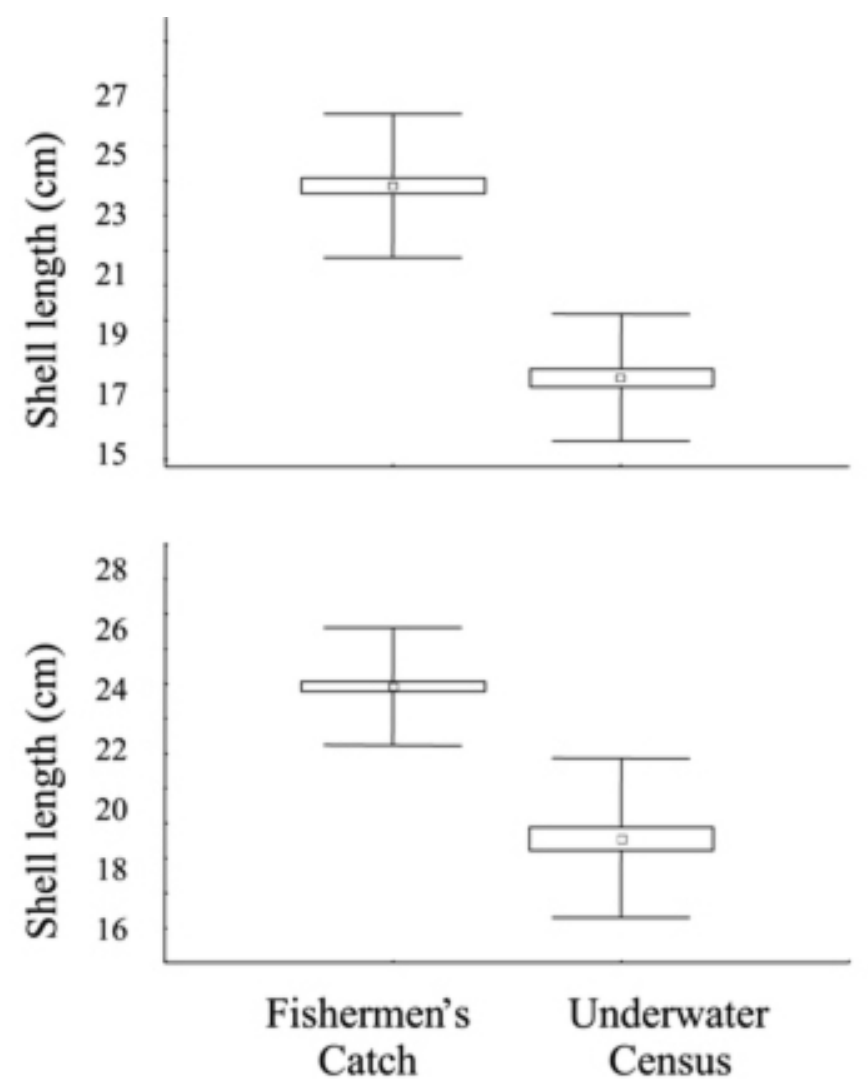

Fishing Area B

Fishing Area D

I Std. Dev.

Std. Err.

Mean temporally concentrate fishing pressure in a few areas of the Channel, allowing other places to recover to the overall benefit of the fishing stock. Clearly, the rotation of fishing areas at various timescales could pose benefits for the long-term sustainability of this social-ecological fishing system, as has been documented in other settings (Jodha 1998, Niamir-Fuller 1998, Berkes 1999).

In sum, the specific combination of information that fishers are able to gather from the biological world provides them with options, opportunities, and constraints that shape their fishing practices. Depending on what these fishing practices are, they can contribute to the maintenance of the biological resilience of the fishery, which in turn supports the development and maintenance of a successful selfgovernance system. My findings suggest the possible existence of fishing rotation practices, as well as the fishers' use of fishing practices that do not threaten the sexual viability of the population, target mostly individuals that have already reproduced, and avoid harvesting in $Z$. marina meadows that serve as no-take fishing areas. These factors, in combination with the reported institutional mechanisms that control fishing effort (Basurto 2005), help to explain the continued biological resilience of the $\mathrm{CDH}$ population in the Channel.

\section{How might fishing practices that promote biological resilience support self-governance?}

The Seri have in place a set of institutional arrangements to control fishing effort that they can monitor and enforce (Basurto 2005). The presence of these fishing institutions has played a 
fundamental role in maintaining a regular level of harvest for approximately 30 years. Without fishing institutions, any biological system would eventually collapse once fishing effort surpassed the regeneration ability of the resource. It is the combination of Seri fishing practices and the presence of institutions controlling fishing effort that accounts for important contributions to the biological resilience of the fishery and the overall maintenance of a successful self-governance system. More specifically, I propose that Seri fishing practices might be providing short-term buffering capacity to the self-governance system. Buffering capacity is needed at times when monitoring or enforcement of access and use controls is not in place to curtail long-term unsustainable fishing pressure. For instance, Basurto (2006) reported that in 2001, up to 70 fishers were fishing in Seri waters, most of who were nonSeri from the neighboring village, where the catch was poor. Many more anecdotal accounts are available, indicating that rule-breaking events are not uncommon. Certainly, monitoring and enforcement mechanisms are not infallible and will not be always in place to address short-term violations to communally agreed-upon access and use controls. If the biological system could not buffer short-term external shocks such as abrupt increases in fishing effort, the system would eventually not be able to sustain constant levels of harvest. The Kino Bay CDH fishery is a case in point. In contrast with Seri fishing grounds, Kino fishers have no significant eelgrass meadows in their fishing areas, which has reduced the likelihood that they would avoid certain areas at times. As a result, they have had less buffering capacity for sudden increases in fishing effort. In addition, Kino fishers have not been able to develop institutional mechanisms to control the access and use of their fishing grounds (Ana Cinti personal communication). Without fishing practices that buffer against shortterm perturbations and institutional arrangements that control fishing effort, the Kino $\mathrm{CDH}$ fishery was eventually overexploited (Moreno et al. 2005).

The example of overfishing by Kino fishers also illustrates that when resource users are not able to develop harvesting practices that provide users with some observable or even intuitive indication that there will be more resource for them to harvest in the future, e.g., practices that avoid fishing in eelgrass meadows that serve as nonfishing zones, they will find little incentive to overcome the upfront costs of organizing into a successful self- governed regime. In contrast, Seri fishers can recognize the difference between the species $A$. tuberculosa and $P$. rugosa before harvesting, allowing them to adjust and respond to changing circumstances in market demand. Several times I observed that when fish buyers decreased the price of A. tuberculosa because of excessive supply (CDHs are mainly marketed fresh), Seri fishers switched to harvest $P$. rugosa, which commands a lower price, and threatened the fish buyer with landing their catch to anyone that offered them a better price (Basurto 2006). Given the large market share that $\mathrm{CDHs}$ harvested from the Infiernillo Channel represent in the overall national market (Sergio Padres personal communication), this strategy allows Seri fishers to remain economically active (i.e., pay for gas and food for the following day), reduce the supply and fishing effort for $A$. tuberculosa, and exert some pressure on the fish buyer to increase the price once market saturation has ceased. In effect, species selectivity has allowed successful collective action with which fishers adapt and respond to the external shock of changing market conditions. If fishers could not distinguish between the species of $\mathrm{CDH}$ and did not think that they would benefit from future available $\mathrm{CDH}$ harvest, they would not find incentives to agree to meet the costs of collective action to develop institutional responses to market pressures.

\section{CONCLUSION}

In sum, I observed a particular combination of Seri fishing practices that do not threaten the sexual viability of the population, target mostly individuals that have already reproduced, avoid harvesting in eelgrass meadows that serve as no-take fishing areas, and possibly originate rotation patterns among fishing grounds. These practices in combination with the presence of institutions that control fishing effort can account for important contributions to the biological resilience of the fishery and the overall maintenance of a successful self-governance system, though constrained by the inability to completely control the entry of outsiders. I propose that two mechanisms allow the maintenance of successful self-governance. First, institutional arrangements whereby monitoring and enforcement can control fishing effort are fundamental for the overall sustainability of the system (Dietz et al. 2003). Second, a combination of fishing practices that promote biological resilience can provide important short-term 
buffering capabilities to the system for times of sudden external perturbation. A complementary and sometimes redundant system in which institutional arrangements provide long-term stability to the system and fishing practices promote biological resilience that buffers short-term perturbations favors self-governance because no monitoring or enforcement rule-set is infallible. No successful self-governed system would be able to survive in the long term if the biophysical system would collapse or enter a trajectory of collapse at the first short-term perturbation.

Finally, I propose that the specific combination of fishing practices described here can also be viewed as precursors for successful self-governance (Wilson et al. 2007). Fishing practices provide incentives with which fishers can surpass the costs of organizing a rule-set to control fishing effort. When fishers are able to readily observe certain biological indicators of the resource such as size, species, differences among fishing areas, or the presence of eelgrass meadows that protect a portion of the target population, fishers are able to rapidly learn how the resource operates. As has been argued elsewhere (Ostrom 2001), fishers can then make calculations about how their fishing harvests will affect the availability of resources in the future. Given that the Seri have nowhere else to go if they overfish their $\mathrm{CDH}$ fishery, they are able to find strong incentives to surpass the upfront and longterm costs of the time and effort spent to devise and agree upon rules with which to self-govern their fishing system.

Responses to this article can be read online at:

http://www.ecologyandsociety.org/voll3/iss2/art20/responses/

\section{Acknowledgments:}

This project was a collaborative effort between the Seri (Comcaác) community and Comunidad y Biodiversidad. Financial support to conduct fieldwork was generously provided by the Mexican Council for Science and Technology (CONACyT), the Inter-American Foundation, and the Wallace Research Foundation. For assistance with fieldwork and the underwater survey, I thank Curtis Andrews, Rocío Covarrubias, Paquita Hoeck, Jen Pettis, Hudson Weaver, Javier Zacarias, and especially the Valenzuela and López Morales families of Punta
Chueca. An earlier version of this paper was presented at the fall 2007 Mini-Conference of the Y673 seminar at the Workshop in Political Theory and Policy Analysis of Indiana University. Mariana Altrichter, Oonsie Biggs, Ana Cinti, Mike Dadswell, Bonnie McCay, Elinor Ostrom, Mike Schoon, Jorge Torre, and two anonymous reviewers kindly offered valuable suggestions that improved the quality of this manuscript. Rocio Covarrubias helped with the map, and David Price provided superb editorial assistance. Any shortcomings are mine.

\section{LITERATURE CITED}

Acheson, J. M. 2003. Capturing the commons: devising institutions to manage the Maine lobster industry. University Press of New England, Hanover, New Hampshire, USA.

Agrawal, A. 2002. Common resources and institutional sustainability. Pages 41-86 in E. Ostrom, T. Dietz, N. Dolšak, P. C. Stern, S. Stonich, and $\mathrm{E}$. Weber, editors. The drama of the commons. National Academy Press, Washington, D.C., USA.

Ahumada-Sempoal, M. A., S. J. SerranoGuzmán, and N. Ruiz-García. 2002. Abundancia, estructura poblacional y crecimiento de Atrina maura (Bivalvia: Pinnidae) en una laguna costera tropical del Pacífico mexicano. Revista de Biologia Tropical 50(3-4):1091-1100.

Angel-Pérez, C., S. J. Serrano-Guzmán, and M. A. Ahumada-Sempoal. 2007. Ciclo reproductivo del molusco Atrina maura (Pterioidea: Pinnidae) en un sistema laguna costero, al sur del Pacífico tropical mexicano. Revista de Biologia Tropical 55 (3-4):839-852.

Baland, J.-M., and J.-P. Platteau. 1996. Halting degradation of natural resources: is there a role for rural communities? Clarendon Press, Oxford, UK.

Bardhan, P., and J. Dayton-Johnson. 2002. Unequal irrigators: heterogeneity and commons management in large-scale multivariate research. Pages 87-112 in E. Ostrom, T. Dietz, N. Dolšak, P. C. Stern, S. Stonich, and E. Weber, editors. The drama of the commons. National Academy Press, Washington, D.C., USA. 
Basurto, X. 2005. How locally designed access and use controls can prevent the tragedy of the commons in a Mexican small-scale fishing community. Society and Natural Resources 18(7):643-659.

Basurto, X. 2006. Commercial diving and the callo de hacha fishery in Seri territory. Journal of the Southwest 48(2):189-209.

Berkes, F., editor. 1989. Common property resources: ecology and community-based sustainable development. Belhaven Press, London, UK.

Berkes, F. 1999. Sacred ecology: traditional ecological knowledge and resource management. Taylor \& Francis, Philadelphia, Pennsylvania, USA.

Berkes, F., and C. Folke, editors. 1998. Linking social and ecological systems: management practices and social mechanisms for building resilience. Cambridge University Press, Cambridge, UK.

Berkes, F., T. P. Hughes, R. S. Steneck, J. A. Wilson, D. R. Bellwood, B. Crona, C. Folke, L. H. Gunderson, H. M. Leslie, J. Norberg, M. Nyström, P. Olsson, H. Österblom, M. Scheffer, and B. Worm. 2006. Globalization, roving bandits, and marine resources. Science 311(17):1557-1558.

Berkes, F., R. Mahon, P. McConney, R. Pollnac, and R. Pomeroy. 2001. Managing small-scale fisheries: alternative directions and methods. International Development Research Centre, Ottawa, Canada.

Bernard, H. R. 1995. Research methods in cultural anthropology: qualitative and quantitative approaches. Alta Mira Press, New York, New York, USA.

Bowen, T. 2000. Unknown island: Seri Indians, Europeans, and San Esteban Island in the Gulf of California. University of New Mexico Press, Albuquerque, New Mexico, USA.

Butler, A. J., and M. J. Keough. 1981. Distribution of Pinna bicolor Gmelin (Mollusca: Bivalvia) in South Australia, with observations on recruitment. Transactions of the Royal Society of South Australia 105:29-39.

Carpenter, D. P. 2001. The forging of bureaucratic autonomy: reputations, networks, and policy innovation in executive agencies, 1862-1928. Princeton University Press, Princeton, New Jersey, USA.

Coen, L. D., and K. L. Heck Jr. 1991. The interacting effects of siphon nipping and habitat on bivalve (Mercenaria mercenaria (L.)) growth in a subtropical seagrass (Halodule wrightii Aschers) meadow. Journal of Experimental Marine Biology and Ecology 145(1):1-13.

Diario Oficial de la Federación. 1970. Resolución sobre dotación de ejido al poblado el Desemboque y su anexo Punta Chueca, en Pitiquito, Son. 28 de Noviembre de 1970. Departamento de Asuntos Agrarios y Colonización, Mexico City, Mexico. Available online at: http://www.dof.gob.mx/busque da detalle.php.

Diario Oficial de la Federación. 1975a. Decreto por lo que se declara que única y exclusivamente los miembros de la Tribu Seri y los de la Sociedad Cooperativa de Producción Pesquera, S. C. L. podrán realizar actos de pesca en las aguas de los esteros y bahías, situados en los litorales del Golfo de California y de los litorales que forman la Isla del Tiburón, localizada en el Mar de Cortés. 11 de Febrero de 1975. Secretaría de Industria y Comercio, Mexico City, Mexico. Available online at: http://www.dof.gob.mx/busqueda detalle.php.

Diario Oficial de la Federación. 1975b. Resolución sobre reconocimiento y titulación de terrenos comunales del poblado denominado Isla del Tiburón, Municipio de Hermosillo, Son. 11 de Febrero de 1975. Secretaría de la Reforma Agraria, Mexico City, Mexico. Available online at: http://w ww.dof.gob.mx/busqueda detalle.php.

Dietz, T., E. Ostrom, and P. C. Stern. 2003. The struggle to govern the commons. Science 302:1907-1912.

Gibson, C. C. 2001. Forest resources: institutions for local governance in Guatemala. Pages 71-90 in J. Burger, E. Ostrom, R. B. Norgaard, D. Policansky, and B. D. Goldstein, editors. Protecting the commons: a framework for resource management in the Americas. Island Press, Washington, D.C., USA.

Hardin, G. 1968. The tragedy of the commons. Science 162: 1243-1248. 
Helm, M. M., N. Bourne, and A. Lovatelli, editors. 2004. Hatchery culture of bivalves: a practical manual. FAO Fisheries Technical Paper Number 471. Food and Agriculture Organization, Rome, Italy. Available online at: http://www.fao.org/ docrep/007/y5720e/y5720e00.htm.

Instituto Nacional de Estadística y Geografía. 2005. XII censo general de población y vivienda. Instituto Nacional de Estadística y Geografía, Mexico City, Mexico. Available online at: http://w ww.inegi.gob.mx/est/contenidos/espanol/sistemas/c onteo2005/iter2005/selentcampo.aspx.

Jackson, J. B. C., M. X. Kirby, W. H. Berger, K. A. Bjorndal, L. W. Botsford, B. J. Bourque, R. H. Bradbury, R. Cooke, J. Erlandson, J. A. Estes, T. P. Hughes, S. Kidwell, C. B. Lange, H. S. Lenihan, J. M. Pandolfi, C. H. Peterson, R. S. Steneck, M. J. Tegner, and R. R. Warner. 2001. Historical overfishing and the recent collapse of coastal ecosystems. Science 293:629-638.

Jodha, N. S. 1998. Reviving the social systemecosystem links in the Himalayas. Pages 285-310 in F. Berkes and C. Folke, editors. Linking social and ecological systems: management practices and social mechanisms for building resilience. Cambridge University Press, Cambridge, UK.

Keen, A. M. 1971. Sea shells of tropical west America: marine mollusks from Baja California to Peru. Second edition. Stanford University Press, Stanford, California, USA.

Kuhlmann, M. L. 1998. Spatial and temporal patterns in the dynamics and use of shell shelters in St. Joseph Bay, Florida. Bulletin of Marine Science 62(1):157-159.

Lansing, J. S. 2006. Perfect order: recognizing complexity in Bali. Princeton University Press, Princeton, New Jersey, USA.

Levin, S. A. 1999. Fragile dominion: complexity and the commons. Perseus, Reading, Massachusetts, USA.

McCay, B. J., and J. M. Acheson, editors. 1987. The question of the commons: the culture and ecology of communal resources. University of Arizona Press, Tucson, Arizona, USA.

Moreno, C., J. Torre, L. Bourillón, M. Durazo, A. H. Weaver, R. Barraza, and R. Castro. 2005.
Estudio y evaluación de la pesquería de callo de hacha (Atrina tuberculosa) en la región de Bahía de Kino, Sonora y recomendaciones para su manejo. Internal report. Comunidad y Biodiversidad, Asociación Civil, Guaymas, Mexico. Available online at: www.cobi.org.mx/index.php?pag=public aciones\&idioma $=$ esp.

Myers, R. A., and B. Worm. 2003. Rapid worldwide depletion of predatory fish communities. Nature 423:280-283.

Netting, R. M. 1981. Balancing on an Alp: ecological change and continuity in a Swiss mountain community. Cambridge University Press, Cambridge, UK.

Newell, R. I. E., T. J. Hilbish, R. K. Koehn, and C. J. Newell. 1982. Temporal variation in the reproductive cycle of Mytilus edulis L. (Bivalvia, Mytilidae) from localities on the east coast of the United States. Biological Bulletin 162(3):299-310.

Niamir-Fuller, M. 1998. The resilience of pastoral herding in Sahelian Africa. Pages 250-284 in F. Berkes and C. Folke, editors. Linking social and ecological systems: management practices and social mechanisms for building resilience. Cambridge University Press, Cambridge, UK.

Niebla Larreta, J. L. 2006. Maduración, desove y desarrollo larvario del callo de hacha, Atrina tuberculosa (Sowerby, 1835) bajo condiciones de laboratorio. Thesis. Universidad de Sonora, Hermosillo, Mexico. Available online at: http://ww w.biblioteca.uson.mx/digital/tesis/wsp tesis detalle. asp?tesis $=10667 \&$ titulo=Maduración, desove y desarrollo larvario de Callo de Hacha, Atrina tuberculosa (SOWERBY, 1835) bajo condiciones de laboratorio\&autor=Niebla Larreta, José Luis.

North, D. C. 1990. Institutions, institutional change, and economic performance. Cambridge University Press, Cambridge, UK.

Ostrom, E. 1990. Governing the commons: the evolution of institutions for collective action. Cambridge University Press, Cambridge, UK.

Ostrom, E. 2001. Reformulating the commons. Pages 17-44 in J. Burger, E. Ostrom, R. B. Norgaard, D. Policansky, and B. D. Goldstein, editors. Protecting the commons: a framework for resource management in the Americas. Island Press, Washington, D.C., USA. 
Ostrom, E. 2005. Understanding institutional diversity. Princeton University Press, Princeton, New Jersey, USA.

Ostrom, E. 2007. A diagnostic approach for going beyond panaceas. Proceedings of the National Academy of Sciences 104(39):15181-15187.

Ostrom, E., and T. K. Ahn, editors. 2003. Foundations of social capital. Edward Elgar Publishing, Northhampton, Massachusetts, USA.

Ostrom, E., T. Dietz, N. Dolšak, P. C. Stern, S. Stonich, and E. Weber, editors. 2002. The drama of the commons. National Academy Press, Washington, D.C., USA.

Ostrom, E., R. Gardner, and J. Walker. 1994. Rules, games, and common-pool resources. University of Michigan Press, Ann Arbor, Michigan, USA.

Parsons, G. J., S. M. C. Robinson, R. A. Chandler, L. A. Davidson, M. Lanteigne, and M. J. Dadswell. 1992. Intra-annual and long-term patterns in the reproductive cycle of giant scallops Placopecten magellanicus (Bivalvia: Pectinidae) from Passamaquoddy Bay, New Brunswick, Canada. Marine Ecology Progress Series 80:203-214.

Pauly, D., V. Christensen, J. Dalsgaard, R. Froese, and F. Torres Jr. 1998. Fishing down marine food webs. Science 279:860-863.

Pinkerton, E., editor. 1989. Co-operative management of local fisheries: new directions for improved management and community development. University of British Columbia Press, Vancouver, Canada.

Richardson, C. A., H. Kennedy, C. M. Duarte, D. P. Kennedy, and S. V. Proud. 1999. Age and growth of the fan mussel Pinna nobilis from south-east Spanish Mediterranean seagrass (Posidonia oceanica) meadows. Marine Biology 133 (2):205-212.

Sala, E., E. Ballesteros, and R. M. Starr. 2001. Rapid decline of Nassau grouper spawning aggregations in Belize: fishery management and conservation needs. Fisheries 26(10):23-30.
Sastry, A. N. 1979. Pelecypoda (excluding Ostrea). Pages 113-292 in A. C. Giese and J. S. Pearse, editors. Reproduction of marine invertebrates. Volume V. Molluscs: Pelecypods and lesser classes. Academic Press, New York, New York, USA.

Schlager, E., W. Blomquist, and S.-Y. Tang. 1994. Mobile flows, storage, and self-organized institutions for governing common-pool resources. Land Economics 70:294-317.

Schlager, E., and E. Ostrom. 1992. Property-rights regimes and natural resources: a conceptual analysis. Land Economics 68(3):249-262.

Schneider, M., and P. Teske. 1995. Public entrepreneurs: agents for change in American government. Princeton University Press, Princeton, New Jersey, USA.

Scott, A. D. 1955. The fishery: the objectives of sole ownership. Journal of Political Economy $\mathbf{6 3}$ (2):116-124.

Sheridan, T. E., editor. 1999. Empire of sand: the Seri Indians and the struggle for Spanish Sonora, 1645-1803. University of Arizona Press, Tucson, Arizona, USA.

Stern, P. C., T. Dietz, N. Dolšak, E. Ostrom, and S. Stonich. 2002. Knowledge and questions after 15 years of research. Pages 445-490 in E. Ostrom, T. Dietz, N. Dolšak, P. C. Stern, S. Stonich, and E. Weber, editors. The drama of the commons. National Academy Press, Washington, D.C., USA.

Strathmann, M. F. 1987. Reproduction and development of marine invertebrates of the northern Pacific coast: data and methods for the study of eggs, embryos, and larvae. University of Washington Press, Seattle, Washington, USA.

Torre-Cosío, J. 2002. Inventory, monitoring and impact assessment of marine biodiversity in the Seri Indian territory, Gulf of California, Mexico. Dissertation. University of Arizona, Tucson, Arizona, USA.

Turner II, B. L., P. A. Matson, J. J. McCarthy, R. W. Corell, L. Christensen, N. Eckley, G. K. Hovelsrud-Broda, J. X. Kasperson, R. E. Kasperson, A. Luers, M. L. Martello, S. Mathiesen, R. Naylor, C. Polsky, A. Pulsipher, A. Schiller, H. Selin, and N. Tyler. 2003. Illustrating 
the coupled human-environment system for vulnerability analysis: three case studies. Proceedings of the National Academy of Sciences 100(14):8080-8085.

Varughese, G., and E. Ostrom. 2001. The contested role of heterogeneity in collective action: some evidence from community forestry in Nepal. World Development 29(5):747-765.

Wade, R. 1994. Village republics: economic conditions for collective action in south India. ICS Press, San Francisco, California, USA.

Wilson, J. 2002. Scientific uncertainty, complex systems, and the design of common-pool institutions. Pages 327-360 in E. Ostrom, T. Dietz, N. Dolšak, P. C. Stern, S. Stonich, and E. Weber, editors. The drama of the commons. National Academy Press, Washington, D.C., USA.

Wilson , J., L. Yan, and C. Wilson. 2007. The precursors of governance in the Maine lobster fishery. Proceedings of the National Academy of Sciences 104(39):15212-15217. 